\title{
EXAMINATION OF EXCHANGE RATE AND INTEREST RATE DIFFERENTIALS FOR UNITED STATES AND MEXICO
}

\author{
Ishaan Roy, Lakshita Joshi, Shaariq Daredia, Krish Verma, Gautam Narayan and Riddhi Kapoor \\ Bachelor of Science in Economics, NMIMS, Mumbai
}

DOI: 10.46609/IJSSER.2020.v05i10.007 URL: https://doi.org/10.46609/IJSSER.2020.v05i10.007

\begin{abstract}
This paper analyses the trading relationship between US and Mexico, by examining the interest rate differentials, domestic rate of inflation in each nation, and productivity ratios, while evaluating its impact on nominal and real exchange rates. This is combined with a focus on interest rate differentials and its impacts on the flow of various types of capital, such as Foreign Portfolio Investment and Foreign Direct Investment, and vice versa. The results indicated that most of the theories proposed by international economics concepts, such as the relationship of interest rates and exchange rates in discerning relative and absolute PPP, were found to be statistically insignificant. However, the major finding was that the nominal exchange rate depicts a one-to-one equalization with productivity ratios, which implies a negative Balassa- Samuelson effect for Mexico. Additionally, it was found that capital flows and interest rate differentials do not affect each other, in terms of statistical significance.
\end{abstract}

Keywords: Balassa-Samuelson Effect, Interest Rate Differentials, Nominal Exchange Rate, Purchasing Power Parity, Real Effective Exchange Rate

\section{Introduction}

\section{Why US and Mexico?}

US and Mexico have been major trade partners, especially since the introduction of the North American Free Trade Agreement (NAFTA) in 1994. Other than that, Mexico is also a top destination for Foreign Direct Investment (FDI) in Latin America, second only to Brazil. This investment is also facilitated by the free-trade agreement, as the top five investors in Mexico are all in free-trade agreements with the country. Nearly half of the $\$ 31.6$ billion FDI that Mexico received in 2018 was from its North American Trade partners (\$12.3 Billion from the United States). 
International Journal of Social Science and Economic Research

ISSN: 2455-8834

Volume:05, Issue:10 "October 2020"

Next, while observing the level of investments across various regions in Mexico, it was palpable that this was mainly concentrated along its shared border with United States. This is widely known as the "border effect" and has also been observed in other trading partners like US and Canada. This shows how the investments by the United States in Mexico's manufacturing sector compose a major part of Mexico's overall FDIs.

\section{USMCA}

NAFTA was one of the most important free trade agreements in the world, as it covered the world's largest free trade area of 450 million people. Between 1993 and 2018, the volume of trade between the three countries (US, Canada, Mexico) quadrupled from \$297 billion to \$1.23 trillion. $34 \%$ of US's total exports and $26 \%$ of its total imports are with Canada and Mexico. This agreement has now been replaced by the new USMCA agreement. It, however, is not extremely inconsistent with NAFTA in any aspect, and most of the clauses are similar.

Free trade policies among countries like US and Mexico are especially important because they share production, i.e. one unit of a commodity would cross borders several times. If tariffs had to be applied each time, the cost would compound, and the finished product would become unaffordable. The USMCA takes care of this aspect and makes sure that shared production is sustainable.

\section{FDI in Mexico}

FDI in Mexico in the previous century was mostly in railways. This type of foreign investment started declining and was much lower in the 1990s than it was in the early 1900s. Hence Mexico's FDI curve in the 20th century is negatively sloped if time were to be considered as the $\mathrm{x}$-axis. Nonetheless, this has not been the trend in the $21^{\text {st }}$ century, with FDI investments steadily increasing. However, there is a great amount of short-term volatility that can be observed, when noticing the trends for FDI in the $21^{\text {st }}$ century.

US became the biggest investor in Mexico around 1960s, when it took over a big share of investments from other previously major investors like UK and France. This was because even though US was the world's biggest borrower in 1913, it began to invest abroad, mainly in its geographical vicinity like Canada, Mexico, and the Caribbean. The manufacturing sector became a famous target for foreign investments in Mexico in the 1960s, and the US still majorly invests in this sector.

\section{Literature Review}




\section{International Journal of Social Science and Economic Research}

ISSN: $2455-8834$

Volume:05, Issue:10 "October 2020"

Marmolejo \& Ventosa-Santaularia, (2018) examined the role of productivity ratios and government debt in influencing the exchange rate. Additionally, it considered excess liquidity supplied by US during the financial crisis of 2008 as a factor for the appreciation of Mexican peso, against the dollar. The paper a factor causing the appreciation of Mexican peso, against the dollar. The paper pinpoints the fall in productivity for Mexico, relative to United States, to be the main reason for the continuing depreciation of the Mexican peso, in spite of various economic reforms conducted by the nation post the implementation of a flexible exchange rate regime in 1994. For this investigation, only the role of productivity ratios has been considered as a determinant of exchange rate, while using their definition of productivity to test the strength of this determinant. Furthermore, this paper provides an empirical explanation for the BalassaSamuelson effect. Based on this paper, the role of productivity ratios and the Balassa- Samuelson effect was included into the modelling of exchange rates.

Hannan (2017) analysed the different determinants that influence the capital flows of a nation, vis-à-vis the United States. It segregates capital flows into private, FDI and FPI, and evaluates each component individually, and investigating its relationship with factors such as interest rate differential, growth differential and trade openness. It considers the two differentials to be push/pull factors, i.e. factors that are associated with area of origin or destination. It also talks about other push and structural factors, such as global aversion risk (log) and institutional quality, respectively. However, one of the objectives of this study was to apply theoretical concepts to explain the determinants to capital flows, while the main aim was to investigate the effect of interest rate differentials on capital flows- thus the focus on other potential factors is limited. Considering that Mexico is one of the 34 countries taken as part of emerging markets, that too relative to United States, makes this paper of prime importance for this discussion. Considering the scarcity of free data on complete capital flows, it was decided to use this research paper to put forth arguments regarding the interest rate differentials and net capital flows.

M. Angeles Villareal \& Ian F. Fergusson (2014) substantiated how trade has exponentially increased between Mexico and US. US exports to Mexico increased by 444\%, and imports from Mexico increased by $603 \%$ from 1993 to 2013. The trickle-down effect of technology from US came because of foreign investment in the Mexican manufacturing sector from US. The relative importance of the value of US and Canadian trade with each other, however, has been falling in recent years. This paper fails to provide adequate intuitive reasoning behind these trends. This could be attributed to the Mexico's overall progress in manufacturing, which has made it a prominent exporter even for the rest of the world.

Davide Gandolfi, Timothy Halliday \& Raymond Robertson (2015) investigated the effect of trade, FDI, and migration barriers. It tested the theory that factor price convergence should follow increased migration, capital flows, and commercial integration. The specific case of US and Mexico was used because all three of the factors had increased between the countries in the 


\section{International Journal of Social Science and Economic Research}

ISSN: $2455-8834$

Volume:05, Issue:10 "October 2020"

past few decades. It found that US-Mexico place premium has remained remarkably stable. Hence wage differences are a consequence of something other than trade, FDI, and migration barriers. With regards to FDI, the paper found that the areas around the US-Mexico border in Mexico had a smaller wage differential as compared to the more internal areas. The border regions also happen to be the place where most of the FDI from US is invested. Hence FDI does stimulate the process of factor price convergence to some extent.

\section{Data \& Methodology}

Data was taken from the years 2009-2018 for countries US and Mexico. This included data on economic indicators such as policy interest rates, nominal exchange rates, effective exchange rates, nominal GDP, money supply and consumer price indices. Data was accumulated from World Bank Datasets, WITS website, US Bureau of Labour Statistics, IMF Datasets, United States Trade Representative Datasets and United States Government Datasets.

Several statistical methodologies were used, such as t-test hypothesis and f-test hypothesis, along with correlation and multiple regression analysis to understand the existence of relationships between nominal exchange rate, real exchange rate, and interest rate differentials on macroeconomic fundamentals and components.

Multiple regression analysis and correlation analysis was utilized to investigate the validity of a relationship between certain economic indicators. There was another use of correlation analysisto understand whether the considered dataset was bridled with the issue of multicollinearity or not.

Mainly, the focus was to discern the impact that certain economic indicators, like productivity, inflation, interest rates and capital flows, have on exchange rate, and also investigating the legitimacy of inversing this relationship. The same was done for interest rate differentials and foreign investment. The t-test hypothesis was utilized to statistically verify the deciphered relationships.

\section{Analysis and Results.}

\subsection{Impacts on Nominal Exchange Rate}

This section monitors the different aspects that influence the Mexican American nominal exchange rate. Through the nominal exchange rate equation ${ }^{1}$, it illustrates that nominal exchange rate is impacted by price levels, i.e. inflation levels, of Mexico and United States. However, theory also suggests that other factors, such as interest rate, differentials tend to affect the exchange rate.

Through a regression analysis, an examination is done, regarding how different factors influence nominal exchange rate. The equation also includes productivity differentials, as a paper by 


\section{International Journal of Social Science and Economic Research}

ISSN: $2455-8834$

Volume:05, Issue:10 "October 2020"

Arnoldo Lopez Marmolejo and Daniel Ventosa-Santaularia ${ }^{2}$ indicate a high level of correlation between productivity differentials and exchange rate, while also evaluating the existence of Balassa-Samuelson effect.

$\ln (E R)=0.425188261-1.457574767 P R-0.033215436 I R+0.001952956\left(i-i^{*}\right)$

where $\mathrm{PR}=$ Productivity $\mathrm{Ratio}^{3}, \mathrm{IR}=$ Inflation Ratio and $\left(i-i^{*}\right)=$ Interest Rate Differential between US and Mexico ${ }^{4}$;

Through this analysis, the p-value of the interest differential $(0.745)$ is greater than the level of significance (0.05), indicating that this factor should not be considered ${ }^{4}$. What the previous line states is that interest rate differential has no significant effect on the exchange rate, hence it should be removed from the equation.

\begin{tabular}{|l|l|l|l|}
\hline Correlation Matrix & Productivity Ratio & Inflation Ratio & Interest Rate Differential \\
\hline Productivity Ratio & 1 & & \\
\hline Inflation Ratio & -0.33976298 & 1 & \\
\hline Interest Rate Differential & 0.116273289 & -0.22097617 & 1 \\
\hline
\end{tabular}

Additionally, when checking the issue of multicollinearity for the regressed equation, it is important to see the correlation of independent variables, as to ascertain which variables can be explained by other independent variables, as means to omit the variable and resolve this issue. By looking at the above matrix, it is clear that there is not a strong association between the independent variables, while the F-Test was significant- indicating that the all of the independent variables jointly help in demonstrating their impact on exchange rates.

However, the variable of interest rate differential was found to be statistically insignificant. Therefore, it would be wise to omit this variable and re-run the regression. When re-adjusting for this, the following equation is derived:

$$
\ln (E R)=0.419302016-1.456218335 P R-0.034081592 I R ;{ }^{5}
$$

Based on this equation, an increase in productivity ratio leads to a more than proportionate decrease in exchange rate. Meanwhile, if the inflation ratio increases, then the decrease in exchange rate value would be less than proportionate to the price ratios. Furthermore, when looking at the correlation between the independent variables, its value was given as -0.338 , which can be an indication that there is no multicollinearity in the revised equation as well.

Also accounting the correlation values between nominal exchange rate and the two factors, productivity ratio has a significant association (-0.969), while inflation ratio has a meagre 


\section{International Journal of Social Science and Economic Research}

ISSN: 2455-8834

Volume:05, Issue:10 "October 2020"

association (0.184)- which is also intimated in the regression equation.

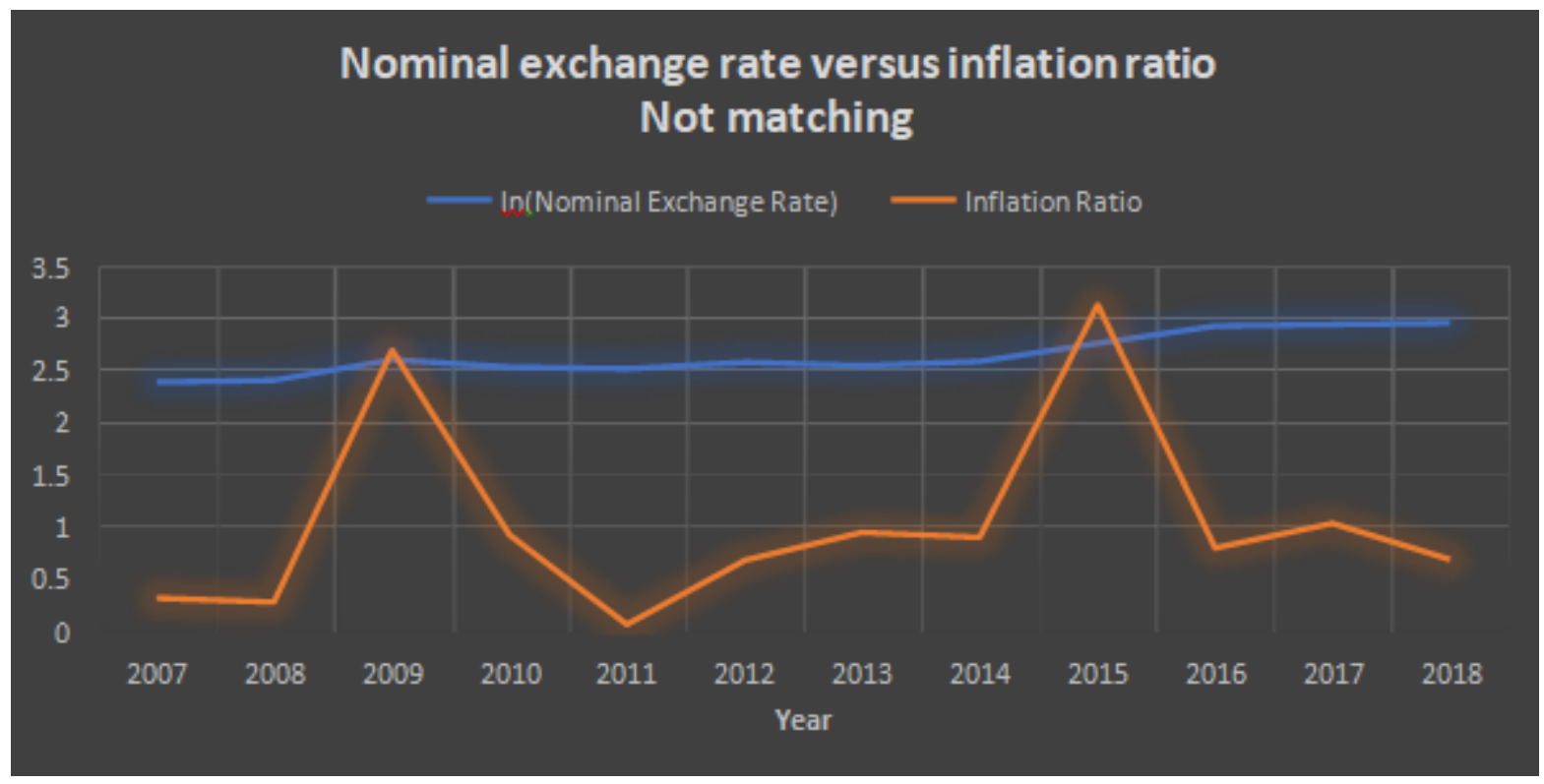

The above graph illustrates that the theoretical nominal exchange rate equation does not hold empirically, given the low correlation with inflation ratios and the low slope value in the regression equation.

Furthermore, this disproves the theoretical Purchasing Power Parity (PPP) interest differential equation $^{6}$, considering that the regression equation does not showcase a one-to-one equalization between interest rate differential and inflation difference. Also, when deriving the equation loglinear model of exchange rate inclusive of interest rate differentials, it was seen that the signs of this variable and price ratios were different, which can prove to be another piece of evidence that the notional implications may not be seen practically.

PPP does not hold empirically possibly due to the existence of transportation costs and consideration of different reference baskets, when calculating inflation, which are assumed to be negligible theoretically. For example, the weightage given to housing in US is 42.634 , while for Mexico, it is 5.11. This illustrates the difference in consumption patterns for housing between the two countries, and this differing pattern stretches to most of the generic goods.

Furthermore, the trade barriers imposed by United States in recent times further hinders the ability for PPP to exist empirically. This would be even more prevalent in the Trump administration, with his stringent inward-looking policies. For example, the new US-CanadaMexico agreement protects Mexican production from tariffs through quota system- which still enacts as a trade barrier.

This creates an additional transaction cost for traders and hinders the applicability of PPP empirically. Another evidence of the existence of transaction costs is corruption costs ${ }^{7}$ - with this 


\section{International Journal of Social Science and Economic Research}

ISSN: $2455-8834$

Volume:05, Issue:10 "October 2020"

cost ascending to around 9\% of GDP, as of 2016. This possibly would have increased with the arrival of Andres Manuel Lopez Obrador as president of Mexico. The existence of such costs implies weaker transparency and unpredictable returns which are more dependent on the favours of the government for investments in Mexico, relative to the US.

\section{NOMINAL EXCHANGE RATE PLOTTED WITH PRODUCTIVITY RATIO}

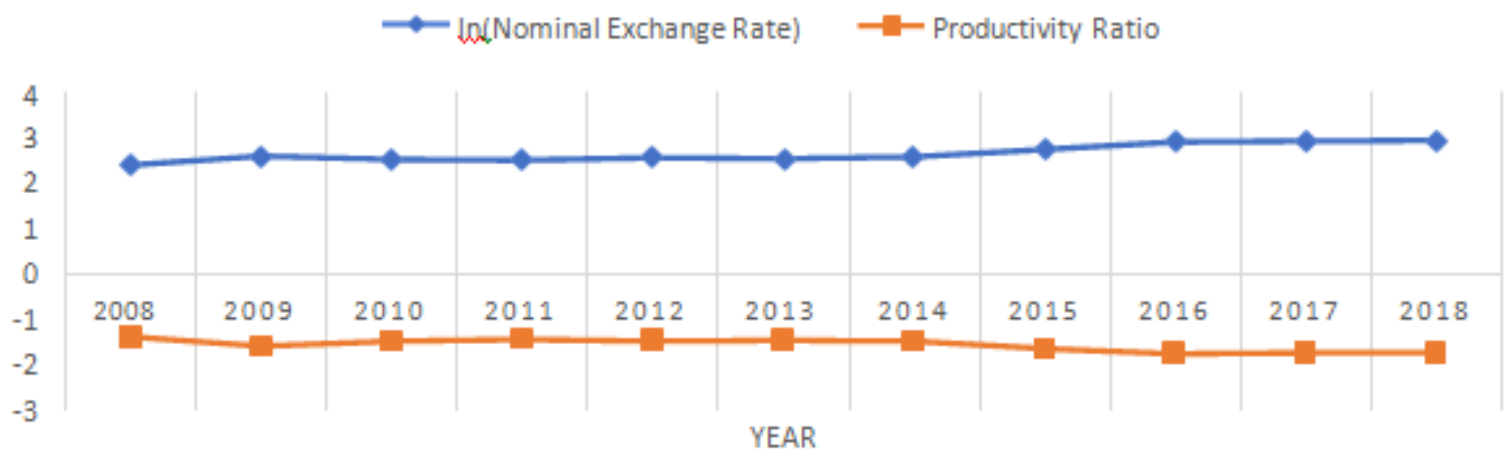

As shown by the correlation value and regression slope value, productivity ratio has a large influence on nominal exchange rate. Given that the productivity ratio has an opposite downward sloping trendline, relative to the nominal exchange rate, it implies that the productivity in US has increased, relative to Mexico, and it has led to a divergence from the nominal exchange rate. It can be said that the productivity ratio, in the graph, is a reflection, from the x-axis, of the graph for nominal exchange rate. If the productivity ratio formula is flipped around, then a similar line would be seen, between the nominal exchange rate and the productivity ratios.

This result can be said to illustrate a negative Samuelson-Balassa effect for Mexico. It assumes that labour productivity in poor countries are relatively less than in richer countries in terms of tradable and non-tradable goods- meaning that prices for these goods would be higher, leading to higher inflation rates. This is represented by a higher CPI inflation index in US for all ten years used, comparative to Mexico.

One of the main reasons for the productivity in Mexico to slow down, relative to United States, can be traced back to the taxation and bureaucratic burdens imposed by their government. Also, assuming that Mexico can be divided into two parts of an economy: one where multinational corporations (MNCs), electronics and auto and aerospace sector firms exist, which are also known as the maquiladora regions, and another, which is home to small and medium sized enterprises and employs $80 \%$ of workers. The latter faces increased operating costs of up to $50 \%$ for a plant opening- which is a major reason for productivity to be relatively lower in Mexico. 
International Journal of Social Science and Economic Research

ISSN: 2455-8834

Volume:05, Issue:10 "October 2020"

This implies that the relative higher levels of productivity seen in the maquiladora regions probably does not outweigh the productivity experienced in the regions of MSMEs.

Hence, productivity ratios significantly affect nominal exchange rate between United States and Mexico, and this matches the notions of the Balassa-Samuelson effect. This is congruous with the results attained by Marmolejo and Ventosa-Santaularia, where the only difference between the results is the time period accounted for this effect and method of derivation.

\subsection{Impact on Real Exchange Rate}

Similar from the derivations for nominal exchange rate, a regression equation will be derived to examine the empirical factors influencing the real exchange rate.

The results are similar to that of nominal exchange rate, for Mexico's REER, i.e. the interest rate differentials are statistically insignificant to be considered (0.855) as its p-value is greater than $0.05^{8}$. Adjusting for this, the equation for real exchange rate is as follows:

\section{Effective Real Exchange Rate Mexico}

$$
=204.4960385-71.61123631 P R+1.49993627 I^{9}
$$

However, when calculating for US' real exchange rate, interest rate differentials and inflation ratio were also coming as statistically insignificant ${ }^{10}$. Adjusting for this, US' real exchange rate equation is:

$$
\text { Effective Real Exchange Rate US }=7.265414719+61.41620152 P R^{11}
$$

When looking at the effect that productivity ratio has, an increase in this ratio indicates a relative increase in US productivity, which can be theoretically associated with an increase in relative output produced. This leads to a real depreciation of the exchange rate. However, the equation illustrates that an increase in productivity ratio leads to a real appreciation- meaning that, theoretically, the transaction demand for money would have a commensurately greater effect, leading to an appreciation. The opposite applies with the US effective real exchange rate, as denoted by a positive slope sign for productivity ratio in this REER's formula. 


\section{International Journal of Social Science and Economic Research}

ISSN: 2455-8834

Volume:05, Issue:10 "October 2020"

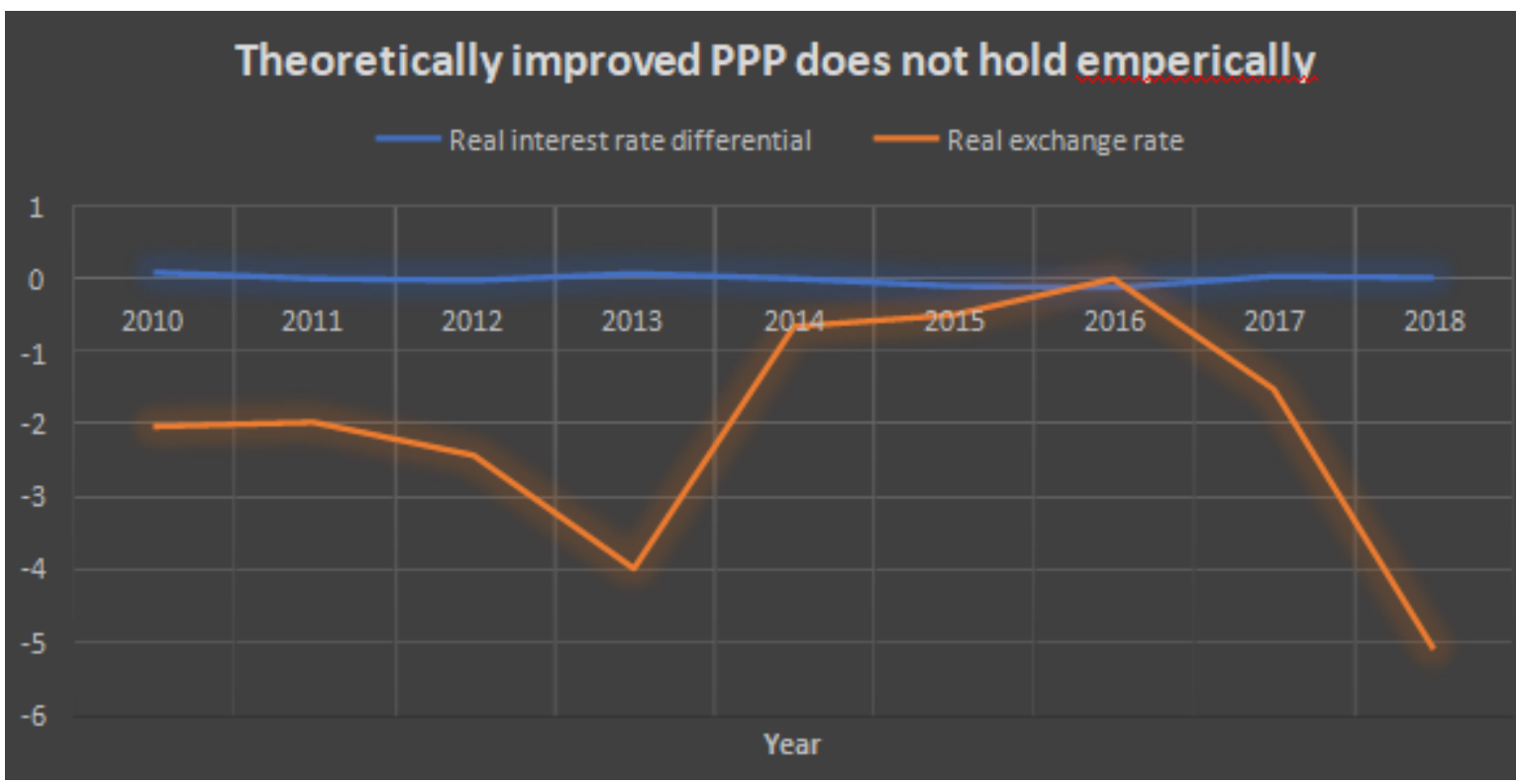

As for inflation ratios in the Mexico REER, they consist of a comparatively smaller equalization effect on the real exchange rate, given that its effects can be monitored by the real interest rate. According to theory, the relative PPP indicates the following:

$$
Q_{M E X / U S}=\frac{E_{M E X / U S} \times P_{M E X}}{P_{U S}} 12
$$

However, by comparing real interest rates differentials with real exchange rate differentials, as seen by the above graph, there was no evidence of interest parity- meaning that relative PPP, in empirical terms, does not hold practically.

It is also evident that interest rate differentials have no effect on capital flow. This means that any fluctuation in interest rates does not cause a significance disruption in the flow of capital ${ }^{13}$. As a result, there is no effect on the trend of exchange rates either.

Furthermore, it is assumed that relative PPP gravitates around 1, due to the fact if nominal exchange rate decreases by a certain proportion, the inflation ratios should increase by the exact same proportion. However, in the previous section, this was proven to not be true.

Additionally, when relative PPP is expected to hold, the expected real interest rates between the two countries are expected to match. However, these rates may differ if there are continuous changes in output markets, like productivity changes in the either of the markets. This latter statement is empirically shown, as the productivity ratio has had an upward-sloping trend, in favour of US- meaning that Mexico's real interest rate should be higher.

\subsection{Impacts Created by Nominal \& Real Exchange Rates}




\section{International Journal of Social Science and Economic Research}

ISSN: $2455-8834$

Volume:05, Issue:10 "October 2020"

Next, we examined the effects that nominal and real exchange rate would have on the trade balance between US and Mexico- through regression and correlation analysis.

Initially, a t-test was used to establish the existence of any association between nominal exchange rate and the components. The null hypothesis was considered as no association between the two variables, while the alternate hypothesis assumes the opposite. It was found that trade balance $(-17.170<-2.262)^{14}$ and net FDI flows between Mexico and USA $(-12.123<-$ $2.262)^{15}$ is associated with nominal exchange rate ${ }^{16}$.

A regression analysis was used to evaluate each individual component's association with nominal exchange rate.

\section{Trade Balance $=34565.45+1825.282$ Nominal Exchange Rate ${ }^{17}$}

Considering that this equation has a significance value of 0.06 , this can be considered as statistically meaningful if the confidence interval is extended to $10 \%$. However, the correlation value (0.609) does not indicate a particularly strong association between the two variables, given that a strong correlation is from 0.8 onwards. Trade barriers can be considered as a significant reason why nominal exchange rate does not influence trade balance as theory predicts, where the latter would assume a strong correlation between trade balance and exchange rate.

Also, due to the existence of time lag, as posited by the J-curve hypothesis, the effect on trade balance may not be seen in the same time period as the change in exchange rate.

Thus, if trade balances are considered to change next year, i.e. time period $t+1$, when exchange rate changes in time period $t$, then the equation, as measured on a yearly basis, is as follows:

\section{Trade Balance $[\mathrm{t}+1]=24930.016+2606.076$ Nominal Exchange Rate $[t]^{18}$}

This equation is significant as the p-value (0.004) is far lower than the threshold of 0.05 . Hence, when it is assumed that an exchange rate shift in the next period is coincided with a change in trade balance in the previous period.

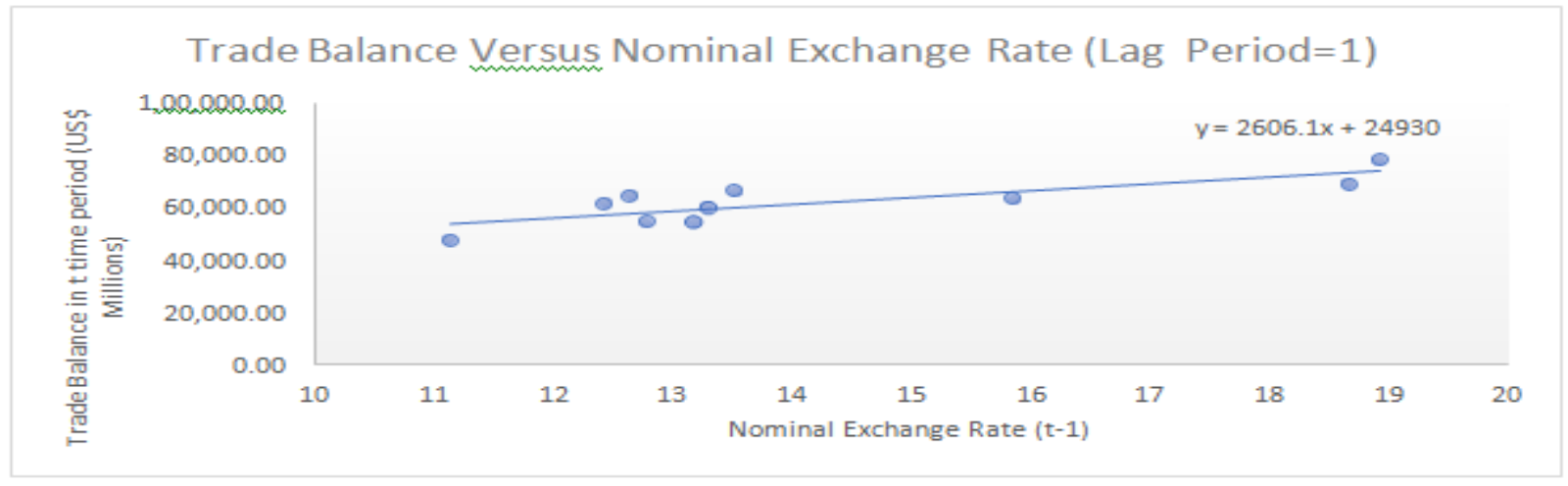




\section{International Journal of Social Science and Economic Research}

ISSN: 2455-8834

Volume:05, Issue:10 "October 2020"

Additionally, the above graph represents the regression line and the data points. Based on the RSquare value, it explains $66.47 \%$ of the deviations present in the data of trade balance. This insinuates that the lagged independent variable has relatively high explanatory powers. This is exemplified further by the greater correlation value $(0.815)$ - insinuating that the time lag for trade balance to adjust exists in the case of US and Mexico. Assuming that Mexican peso depreciates, this time lag exists as people need to adjust to changes in prices of goods and services in the short run. However, in the long run, which is one year in this case, this effect gets reversed and trade balance starts to increase.

Furthermore, when checking the correlation value for the lagged effect of nominal exchange rate on trade balance, but by assuming that the effect would be seen in time period $t+2$, the value was 0.791. This value is close enough to the assumed high correlation threshold minimum of 0.8 , meaning that lagged returns are applicable for 2 years. The equation for this relationship is as follows:

\section{Trade Balance $[\mathrm{t}+2]=2606.076+2962.808$ Nominal Exchange Rate $[t]^{19}$}

This equation is significant as the p-value (0.006) is less than 0.05. The sign is still negative, insinuating that the change in lags does not change the relationship between exchange rate and trade balance. However, for this lag period, a change in nominal exchange rate would result in a higher change in trade balance, comparative to the result found for the lag period of $t=1$.

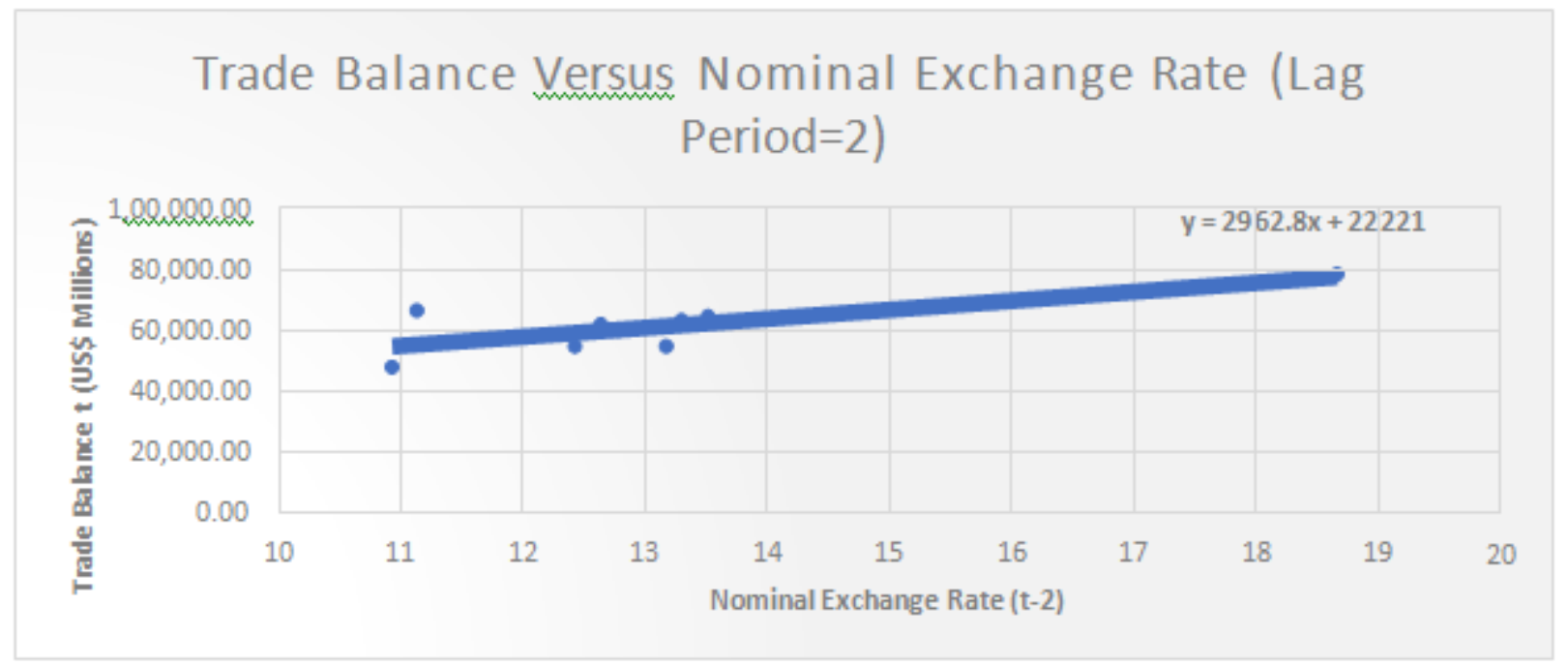

The above graph depicts the illustration of the regression equation against the data points for when the lag period for nominal exchange rate is considered to be $t=2$. The explanatory powers of this lagged variable are lower than when $t=1$, but it is still fairly high, with the independent variable explaining $62.66 \%$ of all deviations in the trade balance data. Hence, a strong case can be 


\section{International Journal of Social Science and Economic Research}

ISSN: $2455-8834$

Volume:05, Issue:10 "October 2020"

made for assuming the J-curve hypothesis to exist within different time frames for the same set of countries in the same time period.

Moving on, talking about the real exchange rate of US and Mexico, we consider that the RER of US and Mexico both affect the trade balance between the two countries. The equation is as follows:

\section{Trade Balance $=245331.67-755.93 R E E R_{U S}-1125.05 R E E R_{M E X} X^{20}$}

The sign indicates that if there is an increase in the REER of either of the countries, then that would lead to a fall in the value of the trade balance. The interpretation of REER is that if the value of the index increases, then it indicates appreciation. Given that appreciation usually does not bode well for maintaining a trade surplus, the theory matches the equation stated above. However, the significance value is higher than $0.05^{21}$, meaning that it is statistically insignificant as well.

Furthermore, the relationship between the effective real exchange rates of the two countries is extremely high, in absolute terms (-0.947), indicating the presence of multicollinearity. This insinuates that trade balance can be explained by including just one of the two variables. Accounting for this, the relationships are as follows:

Trade Balance $=13286.855-459.526 R E E R_{U S}$

\section{Trade Balance $=107988.359-497.144 R E E R_{M E X}$}

However, both these equations are found to be statistically insignificant ${ }^{22}$. These relationships may not be showcased empirically as it has been shown above that nominal exchange rate is not directly translate from/by the inflation ratios. These reasons were mentioned before.

However, the equation which expressed trade balance as a function of the effective real exchange rates of the two countries was found to be statistically insignificant is both independent variables are considered together. This was derived by deciphering the p-value of the F-Test conducting for this equation, and since its value was 0.242 , it can be said that even if both the variables are considered jointly, then their effect is not statistically significant (for a confidence interval of 95\%). This is backed by the previous two equations mentioned above, which says that the effect of either real exchange rates taken individually was found to be insignificant. These results imply that the trade balance maintained between the two nations would likely be a function of other variables. However, since the focus of this paper is primarily on exchange rates and interest rate differentials, this conjecture has not been tested for in this study.

\section{4 . Impact on Capital Flows}


International Journal of Social Science and Economic Research

ISSN: 2455-8834

Volume:05, Issue:10 "October 2020"

Next, this section follows the impact that interest rate differentials have on capital flows. First, the impact of interest rate differentials on net FPI from Mexico, US and net FDI from US to Mexico was examined.

Again, multiple regression equations were formulated to evaluate the effect of these differentials on these three components.

Net FDI $=13421.34369+134.3443321\left(i-i^{*}\right)$
Net FPI US $=-3.05517 \times 10^{11}-20927258711\left(i-i^{*}\right)$
Net FPI Mexico $=-55335757959-6169727054\left(i-i^{*}\right)$
$\left(i-i^{*}\right)=-5.92557-4.3 \times 10^{-11} F P I_{M E X}+3.21 \times 10^{-14} F P I_{U S}+3.15 \times 10^{-5} F D I$
\begin{tabular}{|l|l|l|l|}
\hline Correlation Matrix & FPI Mexico & FPI US & FDI Flows (US to Mexico) \\
\hline FPI Mexico & 1 & & \\
\hline FPI United States & 0.4226 & 1 & 1 \\
\hline FDI Flows (US to Mexico) & -0.0382 & 0.3597 & 1 \\
\hline
\end{tabular}

Looking at the fourth equation, it indicates that the FDI and FPI components have negligible impacts on $i-i^{*}$, meaning that the interest rate differential determines these components. However, all the values for these regression equations have $\mathrm{p}$-values of greater than 0.05 , making it statistically insignificant ${ }^{23}$. Also, given the low correlation that is present between the independent variables, one could argue that multicollinearity does not exist. When investigating further on this econometric issue, by calculating the F-Test for the fourth equation, it indicated statistical insignificance, as the p-value was above 0.05 (deciphered to be 0.63325 ). 


\section{International Journal of Social Science and Economic Research}

ISSN: $2455-8834$

Volume:05, Issue:10 "October 2020"

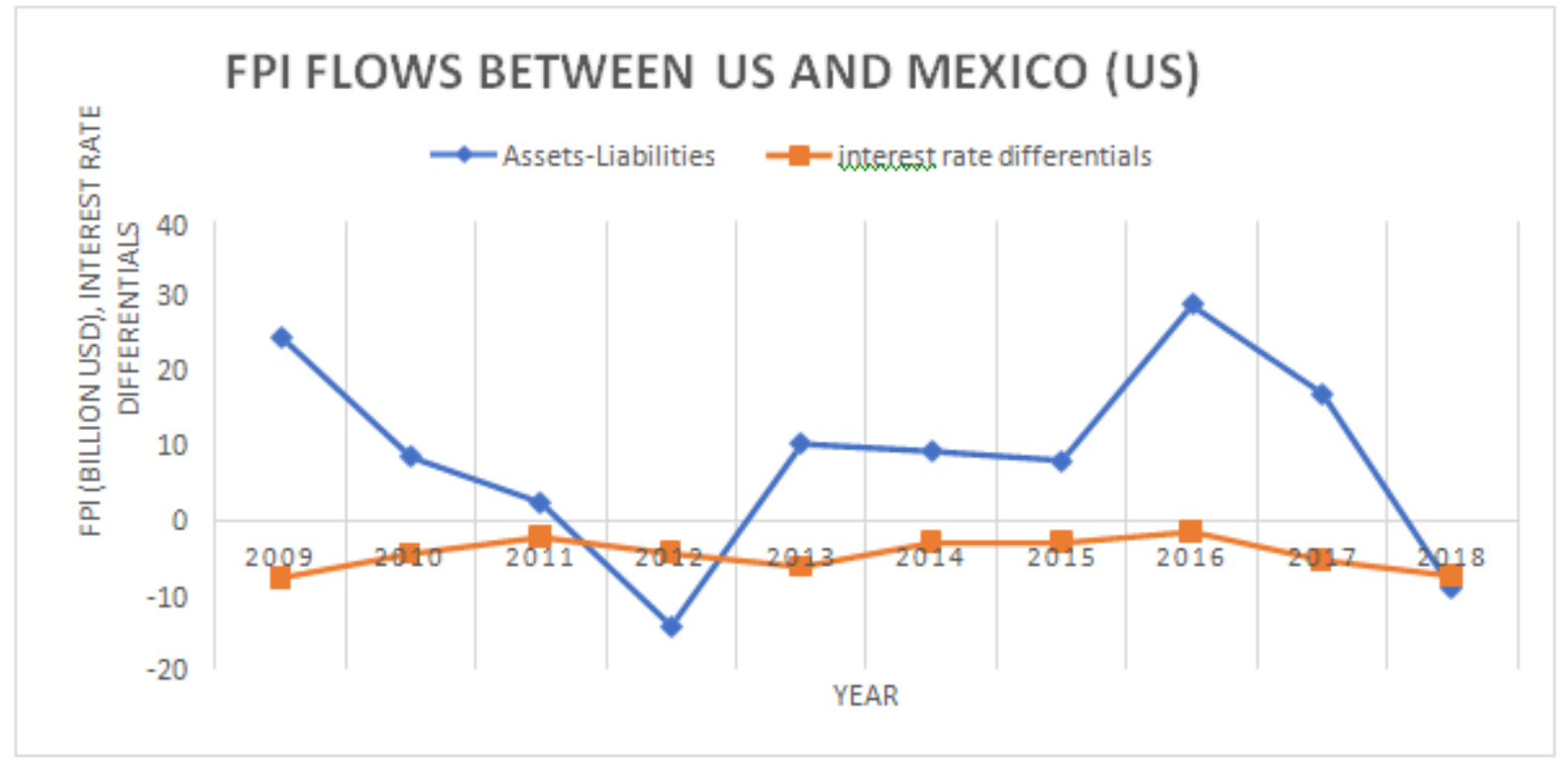

Furthermore, the above graph depicts the relationship between interest rate differentials and net FPI flows ${ }^{5}$ from US to Mexico ${ }^{6}$. It shows a weak correlation between the two variables $(0.138)$. A potential reason for interest rate differential to not be a determinant for capital flows,

i.e. FPI, is due to the risk associated with the country. With geo-political risks and domestic instability existing more in Mexico, relative to US, it makes it a relatively riskier place for investment to occur. This is also showcased by a rise in interest rates, which is positively related to risk factor. However, if an increase in interest rate occurs in United States, then, since it is considered as a safe haven for investment, relative to Mexico, it leads to inflows in favour of US. If the last statement is true, then it disproves the asset theory of money demand, where it talks about interest rates rising due to increase in risk.

Nevertheless, FPI, as depicted by above regression equations, does not necessarily represent the total amount of capital flows between these two countries. A 100 basis points increase in interest rate differential, vis-à-vis the US would increase net total flows, as a percentage of GDP, by 51 basis points (Hannan, 2017). It is important to note that they found net FDI to be statistically insignificant, like the findings found in this paper, but found net FPI and other investment flows to matter, which was not found here.

The paper by Hannan (2017) illustrated that interest rate differentials generally have a relatively positive effect on net capital inflows- i.e. an increase in interest rate differential in favour of the non-US country will lead to greater net capital inflows. As evidence to the previous statements, FDI are not affected by this differential, while net portfolio and private capital inflows are influenced by this differential.

The main reason for FDI not being influenced by interest rate differential is due to its definition. It 


\section{International Journal of Social Science and Economic Research}

ISSN: $2455-8834$

Volume:05, Issue:10 "October 2020"

talks about investment in the form of controlling business ownership by an entity based in another country from that of ownership country.

Meanwhile, FPI for each country, as a function of interest rates, and vice versa, may not have been statistically significant, due to the lack of data availability about complete portfolio flows between the two countries. This meant that proxies were taken, which are not the most accurate representations of capital flows (data was found for net flows for the entire country, not between the two countries).

Nevertheless, considering that FPI consist of securities, whose holdings revolve around interest rate fluctuations, it makes logical sense that interest differentials must be a determinant for capital flows.

Finally, a specific relationship between interest rate differential and FPI flows was derived by considering a general scenario for emerging markets (Hannan, 2017). Given that the derivation of a weak correlation between interest rates differential and FPI flows specific to Mexico, the nation can be said to be an anomaly to the data sets from the Hannan's paper. This is evidenced by the risk profile given to Mexico, BB2- which indicates medium risk.

This risk will only increase in the near future, due to minimal predictability in policy-making, and lower quality of interventionist activities- which can have negative effects on the economy. This would make capital inflows riskier, even if interest rates increase, relative to the time period examined in this study.

Additionally, investor confidence is lower for Mexico, comparative to United States, which further hinders the interest differential impact on capital flows. This can be embodied by statistics such as cost of violence, which is around 22\% of GDP in 2014, along with corruption costs, as mentioned before. This is expected to worsen in the future, as symbolized by the cancellation of the Mexico City airport construction- his decision-making is ostensibly based on personal beliefs, and the role of secretaries and advisers is purportedly limited. This adds to negative expected sentiment associated with Mexico, for investor confidence.

In conclusion, FDI flows and FPI flows are affected negligibly by interest rate differentials, due to factors such as low investor confidence in Mexico, the definition of the two concepts and greater risk associated with Mexico.

\section{Limitations}

During this study, expected rates were assumed to be the $t+1$ value. For example, to find out expected inflation for time period $t+1$, the actual value of inflation in time period $t+1$ was taken. In this scenario, rational expectation theory was assumed to exist, i.e. expected inflation matches actual inflation- but this assumption is not realistic. This was taken due to the lack of availability of data for history of expected rates- which applies not only to exchange rates but also to inflation rates and interest rates. In reality, expected rates differ from actual rates, with its effect 


\section{International Journal of Social Science and Economic Research}

ISSN: $2455-8834$

Volume:05, Issue:10 "October 2020"

being unknown if this data was found.

Furthermore, a real exchange rate was not found between the two countries, or at least how theories define a real exchange rate to be. The real effective exchange rate talks about exchange rate while taking weightages of several foreign currency, and not just one currency, i.e. the home currency, which is US, in the case of Mexico. Again, due to a lack of data availability, it was not possible to find real exchange rate derived by the theoretical equation, and the fact that there was a meagre relationship between nominal exchange rate and inflation ratios may suggest that finding the data for this variable would not alter the results significantly.

Also, since the regression equations calculated have considered time series data, it would be prevalent to check these equations for autocorrelation and heteroskedasticity, as means to ensure that data is stationary. However, due to a limitation in words for this study, it could not be conducted here. Nevertheless, it would be imperative to ensure that the derived equations need to consider these econometric issues, as to not violate the assumptions of classical linear regression model. Additionally, a more comprehensive and accurate study could be conducted if time series analysis were utilized. However, due to a lack of knowledge about such concepts and relevant software at the time of writing this paper meant that these tools could not be utilized.

Finally, due to lack of availability of data for complete capital flows, the complete effects of interest rate differentials on capital flows were not discernible. Only a few concepts were examined, which are net FDI and FPI flows, between countries, and for each country separately (for net FPI flows). Again, if data for private flows was found and utilized, then it may not have made a difference, due to the weak investor confidence and relative high risks that are carried by investing in Mexico. However, the last sentence is based on intuition. Through data, it could have further help prove the last point, but not just for net FPI and FDI, but for complete capital flows. In conclusion, if there was complete availability of data, then this report would have had a more accurate representation of the application of theoretical concepts, such as relative PPP and interest rate parity, and whether they hold in real-life, and to what extent do they hold.

\section{Conclusion}

Through this investigation, the factors influencing nominal real exchange rate and interest rate differentials were decoded. Furthermore, various relationships were examined, such as how nominal exchange rate influences trade balances, along with an examination of how interest rate differentials influence different aspects of capital flows.

Through regression and correlation analysis, it was observed that nominal and real exchange rates are highly influenced by productivity ratios, that indicate a negative Balassa-Samuelson effect for Mexico. Next, inflation ratios had a relatively meagre effect on exchange rates, while interest rate differentials were found to be statistically insignificant.

Next, when discovering how nominal exchange rate influenced trade balance, the presence of a 


\section{International Journal of Social Science and Economic Research}

ISSN: 2455-8834

Volume:05, Issue:10 "October 2020"

time lag was observable, as hypothesized in the J-curve analysis. This countered the relatively (as compared to theory) low correlation coefficient between trade balance and nominal exchange rate of the same time period. On the other hand, real exchange rate did not have effects on trade balances, in statistical terms, due to practical problems, like transportation costs and trade barriers, that hampers the existence of relative PPP empirically.

Finally, when evaluating the effect of interest rate differentials on capital flows, all equations were found to be statistically insignificant- potentially due to incorrect proxies assumed in the investigation. However, Swarnali Ahmed Hannan proved that net capital flows are influenced by interest rate differentials, positively, while also highlighting the importance of this differential in portfolio investment and growth differential in FDI. Nevertheless, given that interest rate differentials do not significantly affect FPI flows in Mexico, it can be said that Mexico is an anomaly from the data set taken by Hannan. Furthermore, reasons such as low investor confidence and relative risk can be explanations for this relationship not existing.

Going forward, there may be other non-economic factors, related to trading, such as geopolitical tensions and a fall in investor confidence (in the sense of Trump wanting to internalize growth, rather than externalize) that could mean that an analysis of capital flows, trading balance, exchange rate and capital flows can become more complex than what has been shown by this investigation, or by previous discourses.

\section{Future Scope}

This study did derive the importance of certain economic factors, when trying to interpret the exchange rate between United States and Mexico. However, a more thorough time-series analysis needs to be done, especially on the reasons proposed for the compliance or divergence of theory and empirical findings, especially since many of the reasons suggested for the divergence of theory and reality is the assumed invalidation of the assumptions made by theoretical viewpoints.

Additionally, structural tests like Chow test needs to be utilized to analyse if the change in presidencies in the United States had a significant structural change in how exchange rates would behave. This is suggested as the country has become more nationalist, in ideological terms, and this is more prevalent with Mexico, if the difference in comments about Mexico by the two presidents of the 2010s are anything to go by.

Finally, with the help of time series analysis, it could give a more accurate perspective about the relevant factors responsible for influencing trade balances, portfolio investments and exchange rates. By utilization of this tool, it could also help in forecasting these aspects, with the help of hypothesized future values.

\section{Acknowledgements}


International Journal of Social Science and Economic Research

ISSN: 2455-8834

Volume:05, Issue:10 "October 2020"

This investigation was conducted as part of an assignment designated under the course, International Economics II. We would like to thank Prof. Nahid Fatema for allowing us to undertake such an enriching investigation, alongside Prof. Hersch Sahay and Prof. Sneha Thayyil for providing their inputs on our study.

\section{References}

\section{Literature Review}

“Congressional Research Service." U.S.-Mexico Economic Relations: Trends, Issues, and Implications, 26 Mar. 2019, pp. 1-40.

Gandolfi, Davide, et al. Trade, FDI, Migration, and the Place Premium: Mexico and the United States, July 2015, pp. 1-49.

Hannan, Swarnali Ahmed. "IMF Working Paper." The Drivers of Capital Flows in Emerging Markets Post Global Financial Crisis, vol. 17, no. 52, Feb. 2017, pp. 1-26.

Marmolejo, Arnoldo López, and Daniel Ventosa-Santaularia. "IDB WORKING PAPER SERIES No IDB-WP-957." Why Does the Mexican Peso Depreciate against the Dollar? The Role of Productivity Differentials, Oct. 2018, pp. 1-33.

Twomey, Michael. A Century of Foreign Investment in Mexico, Oct. 2010, pp. 1-41. Villareal, M. Angeles, and Ian F. Ferguson. NAFTA at 20: Overview and Trade Effects, 28

Apr. 2014, pp. 1-38.

Wilson, Christopher E. Working Together: Economic Ties between the United States and Mexico, Nov. 2011, pp. 1-88.

\section{Articles}

Amadeo, Kimberly. "6 Hidden Benefits of NAFTA.” The Balance, The Balance, 4 July 2019, www.thebalance.com/advantages-of-nafta-3306271.

Arcos, Eduardo. "Mexico: Latin America's next Economic Powerhouse?: GRI." Global Risk Insights, 25 Feb. 2016, globalriskinsights.com/2016/02/can-mexico-reclaim-its-titleas-latin-americas-economic-powerhouse/.

"México." Euler Hermes Global, www.eulerhermes.com/en_global/economicresearch/country-reports/Mexico.html. 
International Journal of Social Science and Economic Research

ISSN: 2455-8834

Volume:05, Issue:10 "October 2020"

"México." United States Trade Representative, ustr.gov/countries-regions/americas/mexico.

“Risk 8: México.” Eurasia Group, www.eurasiagroup.net/live-post/risk-8-mexico.

"Tariff Wars: Duties Imposed by Trump and U.S. Trading Partners." Reuters, Thomson Reuters, 2 Aug. 2019, www.reuters.com/article/us-usa-trade-tariffs-factbox/tariffwars-duties-imposed-by-trump-and-u-s-trading-partners-idUSKCN1UR5YD.

Webber, Jude. "Mexico Struggles to Break Shackles That Bind Productivity." Financial Times, Financial Times, 30 Mar. 2014, www.ft.com/content/999ef49e-b5c6-11e3-81cb00144 feabdc 0 .

\section{Data Sources}

"Archived Relative Importance of Components in the Consumer Price Indexes." U.S. Bureau of Labor Statistics, U.S. Bureau of Labor Statistics, www.bls.gov/cpi/tables/relativeimportance/home.htm.

Dasgupta, Susmita, et al. "World Bank Open Data.” Data, 8 Oct. 2019, data.worldbank.org/. Gonzalez, Elizabeth. "Chart: A Breakdown of Foreign Direct Investment in Mexico." AS/COA,

16 May 2019, www.as-coa.org/articles/chart-breakdown-foreign-direct-investmentmexico.

“IMF Data.” IMF, www.imf.org/en/Data.

"Mexico Trade at a Glance: Most Recent Values."

WITS, wits.worldbank.org/CountrySnapshot/en/MEX.

"U.S. Bureau of Economic Analysis (BEA)." BEA, apps.bea.gov/international/bp_web.

"U.S. Data and Statistics." USAGov, www.usa.gov/statistics.

“US Dollar Peso Exchange Rate (USD MXN) - Historical Chart.” MacroTrends, MacroTrends LLC, www.macrotrends.net/2559/us-dollar-mexican-peso-exchange-rate-historicalchart. 


\section{International Journal of Social Science and Economic Research}

ISSN: 2455-8834

Volume:05, Issue:10 "October 2020"

\section{Appendix}

Appendix A: Regression equation- different determinants on nominal exchange rate

Appendix A: Regression equation- different determinants on nominal exchange rate

\begin{tabular}{|c|c|c|c|c|}
\hline ANOVA & & & & \\
\hline & $d f$ & ss & MS & $F$ \\
\hline Regression & 3 & 0.364003279 & 0.121334426 & 91.9601074 \\
\hline Residual & 7 & 0.009235972 & 0.001319425 & \\
\hline Total & 10 & 0.373239251 & & \\
\hline & Coefficients & Standard Error & tstat & P-value \\
\hline Intercept & 0.425188261 & 0.137599881 & 3.090033649 & 0.017566164 \\
\hline Productivity Ratio & 1.457574767 & 0.089343267 & 16.31432137 & $7.9196 \pi-07$ \\
\hline$i-i^{*}$ & 0.001952956 & 0.005776901 & 0.338062988 & 0.74522817 \\
\hline Inflation Ratio & -0.033215436 & 0.013188639 & -2.518488532 & 0.039898601 \\
\hline
\end{tabular}

Appendix B: Regression equation- different determinants on nominal exchange rate

\begin{tabular}{|c|c|c|c|c|}
\hline ANOVA & & & & \\
\hline & $d f$ & ss & MS & $F$ \\
\hline Regression & 2 & 0.363852486 & 0.181926243 & 155.049157 \\
\hline Residual & 8 & 0.009386765 & 0.001173346 & \\
\hline Total & 10 & 0.373239251 & & \\
\hline & Coefficients & Stondard Error & $t$ stat & P-value \\
\hline Intercept & 0.419302016 & 0.128716329 & 3.257566618 & 0.011569327 \\
\hline Productivity Ratio & 1.456218335 & 0.084167439 & 17.3014452 & $1.26857 \mathrm{E}-07$ \\
\hline Inflation Ratio & -0.034081592 & 0.012200201 & -2.793527187 & 0.023430512 \\
\hline
\end{tabular}

Appendix C: Regression equation- determinants on effective real exchange rate of Mexico

\begin{tabular}{|c|c|c|c|c|}
\hline \multicolumn{5}{|l|}{ ANOVA } \\
\hline & $d f$ & SS & MS & $F$ \\
\hline Regression & 3 & 731.2018897 & 243.7339632 & 74.54132248 \\
\hline Residual & 6 & 19.61869914 & 3.269783191 & \\
\hline \multirow[t]{2}{*}{ Total } & 9 & 750.8205889 & & \\
\hline & Coefficients & Standard Error & t Stat & P-value \\
\hline Intercept & 204.3814783 & 7.540219256 & 27.10550866 & $1.66604 E-07$ \\
\hline Productivity Ratio & -71.6785099 & 4.823828183 & -14.85925849 & $5.84447 E-06$ \\
\hline Inflation Ratio & 1.47391112 & 0.667069557 & 2.209531381 & 0.069187924 \\
\hline $\mathrm{i} \cdot \mathrm{i}^{*}$ & -0.054864111 & 0.288575214 & $=0.190120662$ & 0.855483773 \\
\hline
\end{tabular}




\section{International Journal of Social Science and Economic Research}

ISSN: 2455-8834

Volume:05, Issue:10 "October 2020"

Appendix D: Regression equation- determinants on effective real exchange rate of Mexico

\begin{tabular}{|c|c|c|c|c|}
\hline ANOVA & & & & \\
\hline & $d f$ & SS & MS & $F$ \\
\hline Regression & 2 & 731.0837006 & 365.5418503 & 129.6452062 \\
\hline Residual & 7 & 19.73688829 & 2.81955547 & \\
\hline Total & 9 & 750.8205889 & & \\
\hline & Coefficients & Standard Error & tStat & P-value \\
\hline Intercept & 204.4960385 & 6.979489066 & 29.29957144 & $1.38923 E-08$ \\
\hline Productivity Ratio & -71.61123631 & 4.467361453 & -16.0298729 & 8.93181E-07 \\
\hline Inflation Ratio & 1.49993627 & 0.606261201 & 2.474075971 & 0.042577971 \\
\hline
\end{tabular}

Appendix E: Regression equation- determinants on effective real exchange rate of US

\begin{tabular}{|c|c|c|c|c|}
\hline ANOVA & & & & \\
\hline & $d f$ & SS & MS & $F$ \\
\hline Regression & 3 & 570.598897 & 190.1996323 & 170.8043204 \\
\hline Residual & 6 & 6.681316911 & 1.113552819 & \\
\hline \multirow[t]{2}{*}{ Total } & 9 & 577.280214 & & \\
\hline & Coefficients & Standard Error & tStat & P-value \\
\hline Intercept & 8.464090849 & 4.40027589 & 1.923536401 & 0.102761023 \\
\hline Productivity Ratio & 60.81031544 & 2.815060694 & 21.60177774 & $6.42391 E-07$ \\
\hline Inflation Ratio & 0.55832729 & 0.389284448 & 1.434239905 & 0.201499544 \\
\hline $\mathrm{i}-\mathrm{i}^{*}$ & 0.195860106 & 0.168404991 & 1.163030292 & 0.288976368 \\
\hline
\end{tabular}

Appendix F: Regression equation- determinants on effective real exchange rate of US

\begin{tabular}{|c|c|c|c|c|}
\hline ANOVA & & & & \\
\hline & $d f$ & SS & MS & $F$ \\
\hline Regression & 1 & 567.4309688 & 567.4309688 & 460.8929583 \\
\hline Residual & 8 & 9.849245185 & 1.231155648 & \\
\hline \multirow[t]{2}{*}{ Total } & 9 & 577.280214 & & \\
\hline & Coefficients & Standard Error & tStat & P-value \\
\hline Intercept & 7.265414719 & 4.561637578 & 1.592720727 & 0.149888153 \\
\hline Productivity Ratio & 61.41620152 & 2.860769825 & 21.46841769 & $2.33297 \mathrm{E}=08$ \\
\hline
\end{tabular}




\section{International Journal of Social Science and Economic Research}

ISSN: 2455-8834

Volume:05, Issue:10 "October 2020"

Appendix G: T-test hypothesis- trade balance (thousand \$) with nominal exchange rate

Correlation

\begin{tabular}{|c|c|c|}
\hline t-Test: Two-Sample Assuming & Unequal Variances & 0.715174217 \\
\hline & In(Nominal Exchange Rate) & Trade Balance \\
\hline Mean & 2.641200731 & 106220842.8 \\
\hline Variance & 0.031383519 & $3.82702 E+14$ \\
\hline Observations & 10 & 10 \\
\hline Hypothesized Mean Differer & 0 & \\
\hline $\mathrm{df}$ & 9 & \\
\hline t Stat & -17.1703672 & \\
\hline$P(T<t)$ one-tail & $1.73536 \mathrm{E}-08$ & \\
\hline t Critical one-tail & 1.833112933 & \\
\hline$P(T<t)$ two-tail & $3.47071 E-08$ & \\
\hline t Critical two-tail & 2.262157163 & \\
\hline
\end{tabular}

Appendix H: T-test hypothesis- net FDI flows from US to Mexico (million \$) with nominal exchange rate

\begin{tabular}{|c|c|c|}
\hline & Correlation & \\
\hline t-Test: Two-Sample Assuming Unequal Variances & 0.514998165 & \\
\hline & In(Nominal Exchange Rate) & US to Mexico net FDI (USD, million \$) \\
\hline Mean & 2.641200731 & 12766.48 \\
\hline Variance & 0.031383519 & 11085811.23 \\
\hline Observations & 10 & 10 \\
\hline Hypothesized Mean Difference & 0 & \\
\hline df & 9 & \\
\hline t Stat & -12.12265011 & \\
\hline$P(T<=t)$ one-tail & $3.53032 E-07$ & \\
\hline t Critical one-tail & 1.833112933 & \\
\hline$P(T<=t)$ two-tail & 7.06065E-07 & \\
\hline t Critical two-tail & 2.262157163 & \\
\hline
\end{tabular}

T-Stat is in rejection area, so we null hypothesis is rejected 


\section{International Journal of Social Science and Economic Research}

ISSN: $2455-8834$

Volume:05, Issue:10 "October 2020"

Appendix I: T-test hypothesis- net FPI flows for Mexico (current \$) with nominal exchange rate

\begin{tabular}{|c|c|c|}
\hline & & Correlation \\
\hline \multirow[t]{2}{*}{ t-Test: Two-Sample Assuming Unequal Variances } & & 0.223402382 \\
\hline & in(Nominal Exchange Rate) & Net FPI (BoP, current \$) Mexico \\
\hline Mean & 2.641200731 & -27616888537 \\
\hline Variance & 0.031383519 & $5.25359 E+20$ \\
\hline Observations & 10 & 10 \\
\hline Hypothesized Mean Difference & 0 & \\
\hline df & 9 & \\
\hline t Stat & 3.810189179 & \\
\hline$P(T<=t)$ one-tail & 0.00207596 & \\
\hline t Critical one-tail & 1.833112933 & \\
\hline$P(T<=t)$ two-tail & 0.004151919 & \\
\hline t Critical two-tail & 2.262157163 & \\
\hline
\end{tabular}

T-Stat is in rejection area, so we null hypothesis is rejected

Appendix J: Regression equation determination of J-curve hypothesis, with lag period of $\mathrm{t}=1$

\begin{tabular}{|c|c|c|c|c|}
\hline \multicolumn{2}{|c|}{ Regression Statistics } & & & \\
\hline Multiple R & 0.815311013 & & & \\
\hline R Square & 0.664732048 & & & \\
\hline Adjusted R Square & 0.622823554 & & & \\
\hline Standard Error & 5251.025738 & & & \\
\hline Observations & 10 & & & \\
\hline \multicolumn{5}{|l|}{ ANOVA } \\
\hline & $d f$ & SS & MS & $F$ \\
\hline Regression & 1 & 437353753 & 4.37E+08 & 15.86151 \\
\hline Residual & 8 & 220586170.4 & 27573271 & \\
\hline \multirow[t]{2}{*}{ Total } & 9 & 657939923.5 & & \\
\hline & Coefficients & Standard Error & $t$ Stat & $P$-value \\
\hline Intercept & 24930.01649 & 9463.252919 & 2.634402 & 0.029973 \\
\hline Nominal Exchange Rate $\mathrm{t}-1$ & 2606.076483 & 654.357185 & 3.982651 & 0.004047 \\
\hline
\end{tabular}




\section{International Journal of Social Science and Economic Research}

ISSN: 2455-8834

Volume:05, Issue:10 "October 2020"

Appendix K: Regression equation determination of $\mathrm{J}$-curve hypothesis, with lag period of $\mathrm{t}=2$

\begin{tabular}{|c|c|c|c|c|}
\hline \multicolumn{2}{|c|}{ Regression Statistics } & & & \\
\hline Multiple R & 0.791574087 & & & \\
\hline R Square & 0.626589536 & & & \\
\hline Adjusted R Square & 0.579913228 & & & \\
\hline Standard Error & 5541.679036 & & & \\
\hline Observations & 10 & & & \\
\hline \multicolumn{5}{|l|}{ ANOVA } \\
\hline & $d f$ & SS & MS & $F$ \\
\hline Regression & 1 & 412258271.2 & $4.12 E+08$ & 13.42415 \\
\hline Residual & 8 & 245681652.3 & 30710207 & \\
\hline \multirow[t]{2}{*}{ Total } & 9 & 657939923.5 & & \\
\hline & Coefficients & Standard Error & t Stat & P-value \\
\hline Intercept & 22220.78712 & 11006.78399 & 2.018826 & 0.078201 \\
\hline Nominal Exchange Rate t- 2 & 2962.808373 & 808.6493523 & 3.663898 & 0.006365 \\
\hline
\end{tabular}

Appendix L: Regression equation- REER of US and Mexico on trade balance

\begin{tabular}{|c|c|c|c|c|}
\hline \multicolumn{2}{|c|}{ Regressian Statistics } & & & \\
\hline Multiple R & 0.577483912 & & & \\
\hline R Square & 0.333487669 & & & \\
\hline Adjusted R Square & 0.143055574 & & & \\
\hline Standard Error & 7914.950339 & & & \\
\hline Observations & 10 & & & \\
\hline \multicolumn{5}{|l|}{ ANOVA } \\
\hline & df & ss & MS & $F$ \\
\hline Regression & 2 & 219414851.3 & 109707425.7 & 1.751215674 \\
\hline Residual & 7 & 438525072.1 & 62646438.87 & \\
\hline \multirow[t]{2}{*}{ Total } & 9 & 657939923.5 & & \\
\hline & Coefficients & Standard Error & t Stot & P-value \\
\hline Intercept & 245331.6713 & 188763.3337 & 1.299678632 & 0.234872039 \\
\hline Effective Real Exchange Rate USA & .755 .9275329 & 1028.401036 & -0.735051314 & 0.485199109 \\
\hline Effective Real Exchange Rate Mexico & -1125.05246 & 901.7533305 & -1.247627729 & 0.252284924 \\
\hline
\end{tabular}




\section{International Journal of Social Science and Economic Research}

ISSN: 2455-8834

Volume:05, Issue:10 "October 2020"

Appendix M: Effect of Real Effective Exchange Rate of United States on Trade Balance

\begin{tabular}{|c|c|c|c|c|}
\hline \multicolumn{2}{|c|}{ Regression Stotistics } & & & \\
\hline Multiple R & 0.430437864 & & & \\
\hline R Square & 0.185276755 & & & \\
\hline Adjusted R Square & 0.083436349 & & & \\
\hline Standard Error & 8185.65017 & & & \\
\hline Observations & 10 & & & \\
\hline \multicolumn{5}{|l|}{ ANOVA } \\
\hline & dif & SS & MS & $F$ \\
\hline Regression & 1 & 121900973.8 & 121900973.8 & 1.819285317 \\
\hline Residual & 8 & 536038949.6 & 67004868.7 & \\
\hline \multirow[t]{2}{*}{ Total } & 9 & 657939923.5 & & \\
\hline & Coefficients & Standard Emror & $t$ Stot & P-walue \\
\hline Intercept & 13826.85594 & 35834.2199 & 0.385856201 & 0.709661615 \\
\hline Effective Real Exchange Rate USA & 459.5261719 & 340.6903591 & 1.348808851 & 0.214332793 \\
\hline
\end{tabular}

Appendix N: Effect of Real Effective Exchange Rate of Mexico on Trade Balance

\begin{tabular}{|c|c|c|c|c|}
\hline \multicolumn{2}{|c|}{ Regression Statistics } & & & \\
\hline Multiple R & 0.53107664 & & & \\
\hline R Square & 0.282042397 & & & \\
\hline Adjusted R Square & 0.192297697 & & & \\
\hline Standard Error & 7684.179936 & & & \\
\hline Observations & 10 & & & \\
\hline \multicolumn{5}{|l|}{ ANOVA } \\
\hline & of & Ss & MS & $F$ \\
\hline Regression & 1 & 185566953.2 & 185566953.2 & 3.142719247 \\
\hline Residual & 8 & 472372970.3 & 59046621.28 & \\
\hline \multirow[t]{2}{*}{ Total } & 9 & 657939923.5 & & \\
\hline & Coefficients & Standard Errar & $t$ Stot & P.value \\
\hline Intercept & 107988.3593 & 26035.90948 & 4.147669946 & 0.003219262 \\
\hline Effective Real Exchange Rate Mexico & -497.1440339 & 280.4332075 & -1.772771629 & 0.114202573 \\
\hline
\end{tabular}

Appendix O: Regression equation- interest rate differential on net FDI flows from US to Mexico

\begin{tabular}{|c|c|c|c|c|}
\hline ANOVA & & & & \\
\hline & $d f$ & SS & MS & $F$ \\
\hline Regression & 1 & 578374.5309 & 578374.5 & 0.041055 \\
\hline Residual & 7 & 98613791.17 & 14087684 & \\
\hline \multirow[t]{2}{*}{ Total } & 8 & 99192165.7 & & \\
\hline & Coefficients & standard Error & t Stat & P-value \\
\hline Intercept & 13421.34369 & 3099.453375 & 4.330229 & 0.003437 \\
\hline$i-i^{*}$ & 134.3443321 & 663.0321325 & 0.202621 & 0.845195 \\
\hline
\end{tabular}




\section{International Journal of Social Science and Economic Research}

ISSN: $2455-8834$

Volume:05, Issue:10 "October 2020"

Appendix P-Regression equation- interest rate differential on net FPI flows for US

\begin{tabular}{|c|c|c|c|c|}
\hline ANOVA & & & & \\
\hline & $d f$ & SS & MS & $F$ \\
\hline Regression & 1 & 1. $40344 \mathrm{E}+22$ & 1. $4 \mathrm{E}+22$ & 0.275904 \\
\hline Residual & 7 & $3.5607 E+23$ & $5.09 \mathrm{E}+22$ & \\
\hline \multirow[t]{2}{*}{ Total } & 8 & 3. $70105 \mathrm{E}+23$ & & \\
\hline & Coefficients & Standard Error & t Stat & P-value \\
\hline Intercept & $-3.05517 E+11$ & $1.86245 \mathrm{E}+11$ & -1.64041 & 0.144927 \\
\hline$i-i^{*}$ & -20927258711 & 39841300642 & -0.52527 & 0.61562 \\
\hline
\end{tabular}

Appendix Q-Regression equation- interest rate differential on net FPI flows for Mexico

\begin{tabular}{|c|c|c|c|c|}
\hline \multicolumn{5}{|l|}{ ANOVA } \\
\hline & $d f$ & SS & MS & $F$ \\
\hline Regression & 1 & 1.21984E+21 & $1.22 \mathrm{E}+21$ & 2.549817 \\
\hline Residual & 7 & $3.34882 \mathrm{E}+21$ & 4. $78 \mathrm{E}+20$ & \\
\hline \multirow[t]{2}{*}{ Total } & 8 & $4.56866 \mathrm{E}+21$ & & \\
\hline & Coefficients & Standord Error & tStat & P-value \\
\hline Intercept & -55335757959 & 18061838962 & -3.06368 & 0.018229 \\
\hline$i-i^{*}$ & -6169727054 & 3863771497 & -1.59681 & 0.154338 \\
\hline
\end{tabular}

Appendix R-Regression equation- variables impacting interest rate differential

\begin{tabular}{|c|c|c|c|c|}
\hline \multicolumn{2}{|l|}{ Regression Statistics } & & & \\
\hline Multiple R & 0.519824933 & & & \\
\hline R Square & 0.270217961 & & & \\
\hline Adjusted R Square & -0.167651263 & & & \\
\hline Standard Error & 2.162702662 & & & \\
\hline Observations & 9 & & & \\
\hline \multicolumn{5}{|l|}{ ANOVA } \\
\hline & $d f$ & SS & MS & $F$ \\
\hline Regression & 3 & 8.659337673 & 2.886446 & 0.61712 \\
\hline Residual & 5 & 23.38641401 & 4.677283 & \\
\hline \multirow[t]{2}{*}{ Total } & 8 & 32.04575168 & & \\
\hline & Coefficients & Standard Error & t Stat & P-value \\
\hline Intercept & -5.925572131 & 3.451458033 & -1.71683 & 0.14666 \\
\hline Net FPI (BoP, current \$) Mexico & $-4.32206 \mathrm{E}-11$ & $3.62336 \mathrm{E}-11$ & -1.19283 & 0.286448 \\
\hline Net FPI (BoP, current \$) US & $3.20513 E-14$ & 4.31141E-12 & 0.007434 & 0.994356 \\
\hline US to Mexico net FDI (USD, million \$) & $3.14808 \mathrm{E}-05$ & 0.000238855 & 0.131799 & 0.900283 \\
\hline
\end{tabular}

